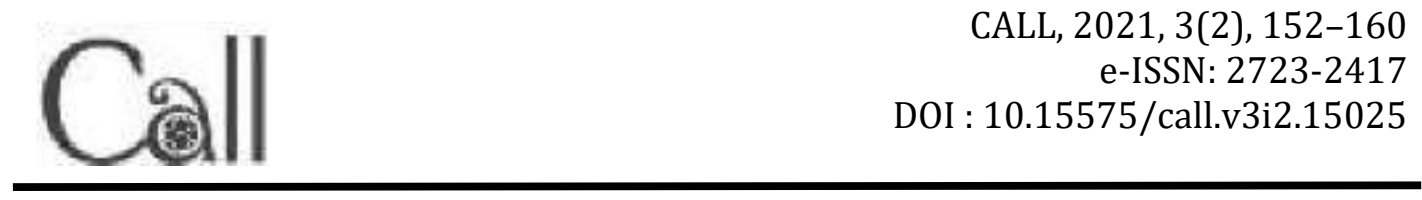

\title{
DEMON AS FORM OF SATIRICAL EXPRESSION IN \\ DRAMA THE TRAGICAL HISTORY OF DOCTOR FAUSTUS
}

\author{
Maulani Fitri Fadlilah,* Pepen Priyawan \\ English Literature, Faculty of Adab and Humanities, UIN Sunan Gunung Djati \\ Bandung, Indonesia \\ e-mail: maulanifitrifadlilah@gmail.com
}

\begin{abstract}
This study focuses on a word or line that is identified as satire in a drama entitled The Tragical History of Doctor Faustus. The data was taken in the form of dialogues from the characters. Demon as a satirical expression means that the words or line identified as satire was built by several elements that are attached with demon characteristics (demonic). Demon is a creature who has clear characteristics as a bad set. The bad character of the demon is representative of satire. The character demon is a representation of ugliness or evil of the object criticized in the drama The Tragical History of Doctor Faustus. Researchers used the descriptive analysis method by Ratna (2004) in conducting this research. Descriptive analysis is a method used to analyze data and facts in the text and then interpret them. The researcher used two theories in seeing the story. Inter-relationship principle and semiotic. The results of this research found three important elements in accordance with the topic of this research. The first is the antagonist character Mephistophilis, the demon. The second is the allusion to Franciscan Friar. Third, the phrase holy shape becomes the devil best is satire. Thus, the combination of elements leads to a demon as a form of satirical expression.
\end{abstract}

Keywords: Satire, Demon, Allusion

\section{INTRODUCTION}

Freedom of speech is a right for humans to express opinions, ideas etc. All opinions basically must-have certain values, aims, and objectives affected by the belief, backgrounds, culture, environment, etc. The right to express opinions still has limitations set by regulations. The regulation could be set, and it comes from government policies, values, and norms in society, etc. Literary work is a product from freedom of speech. Literary work contains meaning, opinions delivered by writer's observations regarding things or phenomena around. According to Damono: 
"The writers use certain devices to convey the meaning. Literary devices can be identified separately but cannot be separated from the purpose." (2016:2)

It's clear enough through his statement that literary works must have a certain meaning. It has purpose, ideas, and things to deliver. The freedom of making literary works also can't escape from the regulations. Damono also explained about tools or devices that writers use to make literary work. The common tools known as literary devices or figurative language. Abrams and Harpham (2012:139) explained that literary devices have the function to produce fresh experiences for the reader. Satire is part of figurative language, which focuses on criticizing something in a "unique" way. The use of satire must be aimed at criticizing something. Abrams (1999:275) satire is a criticism towards something or object that makes the listener or reader laugh and think after hearing or reading it. Satire is meant to make the object criticized look ridiculous that seems to mock the object. There are also several satires which sharply criticize the impression that they are hostile to the object. In addition to satire, there are many other literary devices that can be used in addition to the literary work, literary devices or figurative language also produces various interpretations depending on how the reader understands the story.

The Tragical History of Doctor Faustus is one of the famous or masterpiece literary works written by Christopher Marlowe. Marlowe's contribution to the literary work of drama is beyond doubt. The Tragical History of Doctor Faustus has two written versions known as A text-version (1606) and B text-version (1616). Published in the period of the Dark Age or Middle Age at which time the government was controlled by the Church. Tensions or pros and cons regarding the control of the Church in the Kingdom government are inevitable. The drama tells the story of a famous German scientist or scholar named Faustus who has an affair or deal with Lucifer by selling his life to get the power he wants. Before Faustus met Lucifer, he summoned a demon named Mephistopheles. Faustus ended tragically because he ended up in hell after his affairs ended. This drama showed the religious concept about reward and punishment that represent through hell and heaven. The religious concept that is shown in this drama is Christian or Catholic Church, it can be seen from the names of characters who are related to this religion such as Friar.

Based on the previous explanation, this study examines the statements in this drama story that have demons as satirical expressions towards the government or Catholic Church. The researcher uses selected literary devices like antagonist characters, allusion, and satire to identify the satirical expression. In this study the researcher uses The Tragical History of Doctor Faustus text B-version (1616). Text B-version chosen because it is the long version, and it is the earliest extant edition: 1616.

\section{LITERATURE REVIEW}

Freedom of speech can be expressed in many ways. Depends on what the way that person chose to use. It could be directly or indirect. Literary works use literary devices or figurative language to deliver their message in 
unusual ways because the language they chose is different with its literal meaning. In current situations, some people use satire as their way to express their opinion.

In a study by Muhsyanur, M., Larisu, Z., Sanulita, H., Ertanti, D. W., \& Widada, D. M. (2022) entitled Indonesian Netizens Expression Potentially Satire with the COVID-19 Pandemic on Social Media Facebook: A Digital Ethnoliteration Research focusing on seeing potential information that contains satirical expression by Indonesian netizens on Facebook with COVID-19 Pandemic topic. This study is part of qualitative research that the authors use exploring and examining several statuses in expressions published on Facebook social media as digital exploration techniques to get the data. The data were analyzed by applying pragma-semantic techniques. The results show many types of satire that come from Indonesian netizens. The types of satire are satire-irony, sarcasm, innuendo, cynicism, and satire. The result was summarized as findings in two categories, namely, potentially satire expressions or satire expressions.

Nowadays people still use satire as their way to express their opinions. This study is proof that satire is still related to current conditions.

\section{METHOD}

This study conducts a descriptive analysis by Ratna (2004) as a research method:

"Descriptive analytic method is done by describing the facts which are then followed by analysis. Descriptive analytic methods can also be combined with formal methods. At first, the data is described, to find the elements, then analyzed, and even compared."

His method was chosen because this study pushed the researcher to explain in detail and furthermore. He gives clear instructions to follow. Based on the explanation above, what researchers do to get the data, first is read the story completely. Give a mark to the word or line that is identified has relation with the main topic of this study, satire. The researcher carefully looks at the potential word or line and also focuses on intrinsic and extrinsic elements that have satire on it or bridge to satire. After getting the data the researcher describes and analyzes it using literary devices that are allusion, antagonist character and satire.

As an intrinsic element, the character has a job to deliver the story through the dialogue. According to Diyanni:

"Characters bring plays to life. First and last we attend to characters: to how they look and what their appearance tells us about them; to what they say and what their manner of saying it expresses; to what they do and how their actions reveal who they are and what they stand for." (2004:922)

She explained that characters bring a life to the literature or story. She also gives advice on what is needed to see from the characters. What characters look like, say, action etc. are matters to get information then analyze it as a research object. 
Characters are simply divided into two namely protagonist and antagonist. According to Diyanni (2004:923):

"The antagonist is the character or force against which protagonist struggles. The antagonist may be another character, a culture and its laws or traditions, natural elements, or the protagonist divided against himself."

She said that the function of the antagonist character is to fight against protagonist struggles. We could say that the antagonist character is the protagonist's enemy. That is why conflict appears in the story. The types of antagonists are varied. It could be another character like a human or supernatural being such as a ghost, culture, disaster or natural element, or the protagonist against himself etc. for example, Mephistopheles, Lucifer in drama The Tragic History of Doctor Faust assumed as antagonist character because there are demons.

Demon exists as a creature that lives in darkness, has no mercy, and has a job to tempt humans to the wrong path or disobey God. Giuley (2009:55-60) wrote in her book the explanation about demons in many perspectives. She stated that demons are a type of spirit as misfortune, ruined relationship, sin, and soul loss. If humans have to deal with demons, what humans get only misery in the end. Mephistophilis and Lucifer are demons and have the same characteristic with the definition about demon itself.

One literary device is satire. Abrams (1999:275) explained that satire was an art technique in literature. The simple definition is a way to criticize a subject by making it funny, ridiculous, etc. Satire is one kind of figurative language or in poetry, we know it as a literary device or figurative language like allusion, simile, etc. He also explained that satire used to minimize and demean an object by making the object appear "insulting" or becoming a mockery that invites the reader or listener to "laugh" which leads to amusement, ridicule or invite anger. Satire in that sentence or quote invites wry laughter and anger and refers to statements of hostility. According to Griffin (1994:5) explained satire is problematic (some things have not been resolved or uncertain), open, ambiguous concerning history, more directed at asking questions than giving answers, and the pleasure offered by satire is ambivalent. In short, satire is figurative language that has the function to express a critic for someone or circumstances.

The allusion is one of the figurative languages that functions as an indirect reference and is related to the content of the story. According to McMahan, Funk, Day in (Simanjuntak, 2016), Abrams (1999: 9) and Condliffe in Matrix Education (2020) allusion has a wide range as indirect reference to the name of a famous person, an event, place, or other literary works, important event (history), literature etc. and it depend on the audience or reader knowledge to other text or sources as function to develop the meaning of the story.

Demon as a form of satirical expression cannot be built only by one element; thus, the way the researcher sees the story is through an inter- 
relationship principle and semiotic lens. Ratna (2004:80) said the interrelationship principle in analyzing literary works leads the researcher to focus on every element that cannot be separated from other elements and give a literary works its true meaning. The researcher focuses on three kinds of literary devices. It is in line with what has been explained by Ratna regarding the principle of inter-relationship.

The theory of interrelationship principle needed to be combined with semiotic theory to dig more possibilities for interpretation. According to Ratna:

"Semiotics have functions to express scientifically the whole sign in human life, both verbal and non-verbal signs. Semiotics is the study of everything that can be used to lie." (2004: 105-106)

Semiotic focus on interpreting a sign in human life. Thus, one word or phrase could be seen as a sign. Seeing the literary works with whole possibilities that all elements can offer in the story gives opportunities to the researcher to reach the goal of this study. Method and theories are used by the researcher to get more information about demons as a form of satirical expression in the drama The Tragical History of Doctor Faustus.

\section{FINDINGS AND DISCUSSIONS}

Data 1

Enter MEPHISTOPHILIS.

I charge thee to return, and change thy shape;

Thou art too ugly to attend on me:

Go, and return an old Franciscan friar; That holy shape becomes a devil best.

(Marlowe, 1616, p.12)

In data one, it was Faustus that talked to Mephistophilis. The quote above is a monolog by Faustus. The monolog shows the first meeting between Faustus and Mephistophilis. Mephistophilis summoned by Faustus through dark magic that he learned from his friends. The reason why Faustus learned dark magic is because he wants to have supranatural power. Faustus wants supernatural power because he is not satisfied with everything that he has. Finally, Faustus sells his soul to the Devil. The devil is master from Mephistophilis and through Mephistophilis Faustus succeeds in getting what he wanted. Mephistophilis is a demon and is identified as a supernatural being. Based on the quote Faustus asks Mephistophilis to change his shape from ugly to devil best. The ability to change shape identified him as a supernatural being. Faustus wants Mephistophilis to change his shape into Franciscan friar.

The first element is allusion. Franciscan friar identified as allusion because it reversed to something that had existed, not a character made originally by the writer. The second element is the line that holy shape becomes a devil best as satire. Both elements are related to one another. The first explanation is identified Franciscan friar as allusion. McMahan, Funk, 
Day in Simanjuntak (2016) stated that allusion is indirect references to famous persons, events, places, or to other literary works of literature in poems, novels, stories, and plays. Based on the quote line three it was said to be an old Franciscan friar. What is friar? Oxford (2020) friar is a member of any certain religious orders of men, especially the four mendicant orders (Augustinians, Carmelites, Dominicans, and Franciscans). The four mendicants are part of Roman Catholic as communities of men who in the past traveled around teaching about Christianity. They stayed in the church and lived for life by asking other people for food or depending on "tribute" from adherents of Catholic Christianity. The friar is usually dressed by wearing a robe. The robe color is usually black or dark brown.

In the journal entitled Franciscan Prophets and Inquisition (1226-1326) by Anderson (2018) explains the irregularities of this order ${ }^{1}$ regarding the suspicion of rules made by them and prophetic claims. In his journals he explained that the Franciscans considered or claimed Francis to be a prophet or had a prophetic spirit, to explain how Francis of Assisi, who was never formally educated, could preach, and find a new order. The claim made by the friars and quite controversial was that it ruled in the Fourth Lateran Council in 1215 that all new orders ${ }^{1}$ should use existing rules and strictly limit who could preach. Francis, who lacked a formal religious formation, wrote his own rules.

The explanation about the Franciscan Friar at that time according to Anderson regarding the deviations made by the Franciscan Friars had a real impact on the life of the government during the Dark Age because the Catholic Church controlled the government. One of the events that picture the Dark Age period was during the reign of King Henry VIII where the Church dominated the government rather than the Kingdom. Beddal (2006) The Church at that time was richer than the King of England. Those happened because people at that time believed that life after death was very important to them. The way to have this life after death people must "buy it" to the Church. Even the poor farmers gave 10 percent of their food or agricultural produce to the Church, so they felt like they bought a better life after death for them. There were also people who worked on Church land without being paid. Then, the rich buy at a high price. Because life after death was considered so important at that time, few people reached the age of fifty.

Based on the explanation above, the phenomena or incident at Dark Age or Early Middle Age the researcher could see the connection why in drama The Tragic History of Doctor Faustus character Mephistophilis change his shape into Franciscan friar, and it brings the statement that holy shape becomes a devil best as "mockery" or critic. The second explanation the researcher identified it as satire. According to Griffin (1994:5) explained satire is problematic (some things have not been resolved or uncertain), open, ambiguous concerning history, more directed at asking questions than giving answers, and the pleasure offered by satire is ambivalent. The sentence shows problematic and ambiguous issues concerning history. It becomes problematic because it makes people ask about what happens behind. The ambiguity cannot be denied because the reader does not know

${ }^{1}$ Order $=$ a group of people living community, especially monks or nuns in a religious 
who or what it is aimed at. Oxford Learner's Dictionaries (2020) the state of having more than one possible meaning the reader who read this will have a different perspective. And as Griffin said the pleasure offered by satire is ambivalent. Oxford Learner's Dictionaries (2020) ambivalent mean having or showing both positive and negative feelings about somebody/something or forked opposing. The words holy and devil totally do not suit or opposite. Those words have different meanings and places. The contradiction from the word made it more obvious that it was a satirical statement.

The satirical statement made the word devil in the sentence as the form meaning of the critic. Holy is an adjective word while devil is a noun. Merriam-Webster (2020) holy is exalted or worthy of complete devotion as one perfect in goodness and righteousness means a characteristic if in person who obey God as a loyal servant as a form of loyalty and has good personality while devil is the personal supreme spirit of evil often represented in Christian belief as the tempter of humankind, the leader of all apostate angels means devil is evil creature who disobey God and tempting humans to disobey God.

The researcher thinks that the author, Marlowe, tried to deliver his argument or criticism towards the Church or Catholic. He gave his satirical statements to the Church about whether people who are "holy" or brand themselves holy commit a "crime" or deliberately use "holiness" as a cover for committing that crime. The argument about holy and crime is researcher thought based on the allusion. The researcher stated that the line or sentence that holy shape become the devil best is satire towards the Roman Catholic Church.

Based on the explanation about the original story, Faust is a folklore and the value of the folklore itself made the character Mephistophilis have strong characteristics, and the character is familiar to German people that Mephistophilis is representative of the devil. According to Guiley (2009) in his book entitled The Encyclopedia of Demon and Demonology Mephistopheles or Mephistophilis is a demon and representative of the devil who is the main figure in the faust legend. Mephistopheles was more of a literary figure than an amalgamation of mythology and demonology. He is usually depicted as a tall man wearing black clothes.

Based on the explanation above, Mephistophilis is not a creature that is mentioned in religion or culture perspective. Mephistophilis is part of literature figure that first came from folklore. Britannica (2020) also explained that Mephistophilis is a fictional character that belongs essentially to literature. There is no integral part of the magic and demonological traditions that predate him for thousands of years. He is only mentioned in the magic manual that is associated with Faust. Mephistophilis is a demon and Guiley (2009) explained that demons are the lower agents of evil. It means he has a master or leader who led him, and the master certainly comes from the same sources as him.

The fact is that Mephistophilis is a literary figure who represents a demon. That fact gives the sense and strong character that Mephistophilis or he is the true evil for humans. And continue to the previous analysis about equated Mephistophilis and Franciscan friar. It has been revealed before that Mephistophilis is a demon. Guiley (2009:74) explained that in Christianity perspective demons are spirits who serve Satan as a purpose to ruin the 
human soul and all demons are evil. Demon also explained as supernatural beings who disturb humans. Based on the etymonline (2020) word demon comes from Latin daemon meaning spirit, from Greek daimon meaning deity, lesser god. It appeared for the first time at 1200 and has the meaning of an evil spirit. In Greek perspective daimon or demon could be both good and evil but, in most cultures, demon is "troublemaker" in human life. Demon is a spirit that is lower than the devil or Satan. It could be concluded that simile elements in this drama categories as demonic feature while satire elements categories as satanic feature.

\section{CONCLUSION}

The result of the analysis is the phenomena of the equated Franciscan friar with Mephistophilis. It all began with the Franciscan friar equated with the character Mephistophilis. He mentions Mephistophilis changing his shape into a Franciscan friar in the story. How could a demon change its shape into a friar? It can but why? Using allusion and satire led to exploring more about who is a Franciscan friar and what had been happening in the past. The history reveals the phenomena in the Dark Age or Early Middle Age period about church domination, Roman Catholic Church and Franciscan friar had a relationship with it. The circumstances that happened in the past about church domination, church richer than kingdom because people "buy" the life after death to church and because of that belief only a few people at that time reach until the age of fifty. Based on the circumstance explanation before it helps the researcher to give a good explanation about the reason to who or what it aimed and the function of satire that the researcher found in this drama. Thus, researchers combined all these elements into a demon that is representative of a form of a satirical expression.

\section{REFERENCES}

Abrams, M. (1999). A Glossary of Literary Terms Seventh Edition. Boston: Thomson Learning, Inc.

Abrams, M., and Harpham G. G. (2012). A Glossary of Literary Terms Tenth Edition. Boston: Wadsworth, Cengage learning.

Anderson, C, C. (2018). Franciscan Prophets and the Inquistion (1226-1326). New York: Fordham University. Retrieved from:

Religions | An Open Access Journal from MDPI

Condliffe, P. (2020, September 27). Literary Techniques: Allusion. Retrieved from: https://www.matrix.edu.au/literary-techniques-allusion/

Damono, S. J. (2016). Buku Apresiasi Seni: Bilang Begini Maksudnya Begitu. Jakarta: PT Gramedia.

Diyanni, R. (2004). Literature Approaches To Fiction, Poetry, And Drama. New York: McGraw-Hill

Griffin, D. (1994). Satire: A Critical Reintroduction. Kentucky, UK: The University Press of Kentucky.

Guiley, R. (2009). The Encyclopedia of Demons and Demonology. New York: Facts On File. Retrieved from 
https://epdf.tips/queue/the-encyclopedia-of-demons-anddemonology.html

Muhsyanur, M., Larisu, Z., Sanulita, H., Ertanti, D. W., \& Widada, D. M. (2022). Indonesian netizens expressions potentially satire with the COVID-19 pandemic on social media Facebook: A digital ethnoliteration research. Linguistics and Culture Review, 6(1), 55-69.

Retrieved from https://doi.org/10.21744/lingcure.v6n1.1942

Ratna, N. K. (2004). Teori, Metode, dan Teknik Penelitian Sastra. Denpasar: Pustaka Pelajar.

Simanjuntak, Rahayu and Fauzi. (2016). Figurative Language in Westlife's Second Album Coast to Coast. Riau: University of Pasir Pengairan. 